\title{
Analysis of maternal serum and urinary lipocalin-2 levels
}

\author{
Yeşim Bayoğlu Tekin', Ülkü Mete Ural', Aynur Kırbaş², Şenol Şentürk', Figen Kır Şahin' \\ ${ }^{I}$ Department of Obstetrics \& Gyneceology, Faculty of Medicine, Recep Tayyip Erdoğan University, Rize, Turkey \\ ${ }^{2}$ Department of Biochemistry, Faculty of Medicine, Recep Tayyip Erdoğan University, Rize, Turkey
}

\begin{abstract}
Objective: Lipocalin-2 is a glicoprotein secreted by leukocytes. It is known that lipocalin-2 levels are affected in maternal blood and urine depending on the endothelial damage induced by preeclampsia, and hyperglycemia created by gestational diabetes. However, there are not sufficient studies investigating the levels in healthy pregnants. In our study, we aimed to determine the changes in lipocalin-2 levels of healthy pregnant women.

Methods: This study was carried out as cross-sectional and casecontrolled. Lipocalin-2 levels were determined in blood and urine at first and third trimesters in the same patient group and they were compared. Also, full blood parameters, biochemical and urinary data of the cases were also evaluated.

Results: Lipocalin-2 levels decrease at a statistically significant level in both maternal blood and urine at the third trimester $(\mathrm{p}<0.05)$. However, no significant change was found in other hematologic, biochemical and urinary parameters $(\mathrm{p}>0.05)$.

Conclusion: Lipocalin-2 is a new marker used in the early diagnosis of gestational complications such as preeclampsia and gestational diabetes. It is seen that lipocalin-2 levels in healthy pregnant women decrease to lower levels in third trimester compared to first trimester. However, further studies are required with more populations where maternal serum and urine levels are determined longitudinally.
\end{abstract}

Keywords: Pregnancy, lipocalin-2, biochemical marker.

\section{Introduction}

Lipocalin-2 is a glycoprotein weighing $25 \mathrm{kDa}$ from lipocalin family. It was first defined as a matrix protein in granules within human neutronphiles. ${ }^{[1]}$ In different cell types, it has a role as a growth and differentiation factor.

\section{Özet: Maternal serum ve üriner lipokalin-2 düzeylerinin değerlendirilmesi}

Amaç: Lipokalin-2 lökositlerden salgılanan bir glikoproteindir. Preeklampsinin indüklediği endotel hasarına ve gestasyonel diyabetin oluşturduğu hiperglisemiye bağlı olarak maternal kanda ve idrarda lipokalin-2 düzeylerinin etkilendiği bilinmektedir. Ancak sağlıklı gebelerdeki düzeylerini araştıran yeterli sayıda çalışma bulunmamaktadır. Bu çalışmada sağlıklı gebelerde lipokalin-2 düzeylerindeki değişikliklerin belirlenmesi amaçlanmıştır.

Yöntem: Bu çalışma kesitsel ve vaka kontrollü olarak yürütülmüştür. Aynı hasta grubundan ilk ve üçüncü trimesterde kan ve idrarda lipokalin-2 düzeyleri belirlenerek karşılaştırılmıştır. Ayrıca olguların tam kan parametreleri, biyokimyasal ve üriner verileri de değerlendirilmiştir.

Bulgular: Lipokalin-2 düzeyleri hem maternal kanda hem de idrarda üçüncü trimesterde istatistiksel olarak anlamlı düzeyde düşmektedir $(\mathrm{p}<0.05)$. Ancak diğer hematolojik, biyokimyasal ve üriner parametrelerde anlamlı değişiklik saptanmamıştır ( $>0.05)$.

Sonuç: Lipokalin-2 preeklampsi ve gestasyonel diyabet gibi gebelik komplikasyonlarının erken tanısında kullanılan yeni bir markerdir. Sağlıklı gebeliklerde lipokalin-2 seviyelerinin ilk trimestere göre 3. trimesterde daha düşük seviyelere indiği görülmektedir. Ancak daha geniş olgu serileri ile longitudinal olarak maternal serum ve idrar düzeylerinin belirlendiği çalışmalara ihtiyaç vardır.

Anahtar sözcükler: Gebelik, lipokalin-2, biyokimyasal marker.

Its expression was found in many organs such as liver, kidney and adipose tissue. It was shown that it is also secreted at higher rates in also inflammatory reactions. ${ }^{[2]}$

It has been determined that lipocalin-2 is an inflammatory marker closely associated with insulin resistance and hyperglycemia, and has a role to create insulin resist-
Correspondence: Yeşim Bayoğlu Tekin, MD. Recep Tayyip Erdoğan Üniversitesi Tıp Fakültesi, Kadın Hastalıkları ve Doğum Anabilim Dalı, Rize, Turkey. e-mail: yesimbay@yahoo.com

Received: October 4, 2014; Accepted: January 12, 2015

Please cite this article as: Bayoğlu Tekin Y, Ural ÜM, Kırbaş A, Şentürk Ş, Kır Şahin F. Analysis of maternal serum and urinary lipocalin-2 levels. Perinatal Journal 2015;23(1):30-33.

(c)2015 Perinatal Medicine Foundation
Available online at: www.perinataljournal.com/20150231007 doi: $10.2399 /$ prn.15.0231007 QR (Quick Response) Code:

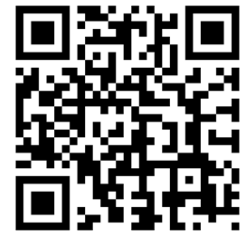


ance for gestational diabetes. ${ }^{[3]}$ It was shown that it is secreted from mature renal epithelium, and it is useful to identify renal damage at early period. Also, it was found that maternal lipocalin-2 levels increased at the early period depending on the preeclampsia. ${ }^{[4]}$

Although lipocalin-2 levels were found to be high in gestational complications such as preeclampsia and gestational diabetes in the literature, there are no sufficient studies evaluating lipocalin-2 levels in normal pregnancies and changes during pregnancy. Our aim in this study is to evaluate lipocalin-2 levels in healthy pregnant women and to determine changes during pregnancy. In this way, it would be more significant to understand if the changes found in gestational complications are physiological responses or the results of the disease pathogenesis. In our study, we aimed to determine and compare lipocalin-2 values at first and third trimesters in healthy pregnant women not complicated by any pregnancy-induced diseases, and to identify the changes in lipocalin-2 levels during pregnancy.

\section{Methods}

This is a cross-sectional case-controlled study. The study was carried out for a year in antenatal polyclinic of a university hospital. The study was approved by the local ethics committee of the university, and the consents of the participants were received by informing them about the study.

Pregnant women between 18- and 35-year-old referred to the hospital for their first antenatal visit were included in the study. Patients with chronic hypertension, preeclampsia, pregestational diabetes history or those diagnosed with gestational diabetes in their previous pregnancies were excluded from the study. Also the patients with the history of renal, cardiovascular, autoimmune and hepatobiliary system diseases were excluded from the study.

First venous blood and urine samples were collected from the patients who referred within their first trimester during their 9-12 weeks of gestation and found to have single alive fetus. Second blood and urine samples were collected at the visit carried out between 34 and 36 weeks of gestation. Blood and urine samples were first centrifuged and then separated as supernatant, and kept at $-20^{\circ} \mathrm{C}$. Full blood parameters and routine biochemical and urinary analyses of the participants were done concurrently in order to determine possible additional pathologies and hematologic, biochemical and urinary anomalies which may be induced by pregnancy.
Lipocalin-2 serum and urine levels were studied by ELISA method and according to the recommendations of Biovender (Research and Diagnostic Products, Heidelberg, Germany). Intra-assay and inter-assay coefficients of variation $(\mathrm{CV})$ were found as $7.5 \%$ and $9.7 \%$. Sensitivity was calculated as $0.02 \mathrm{ng} / \mathrm{ml}$.

Statistical analysis was carried out by SPPS statistical software (SPSS Inc., Chicago, IL, USA) version 17.0. Normal distribution of the data was tested by Kolmogorov-Smirnov test and Lilliefor's correction test. The data displaying normal distribution were provided as mean \pm standard deviation. Paired-sample test was used to compare first and second blood and urine samples. The value $\mathrm{p}<0.05$ was considered statistically significant.

\section{Results}

Forty healthy pregnant women who referred in their first trimester were included in the study. Five of the cases did not come for their visits. Two cases were excluded from the study due to gestational diabetes and one case due to preeclampsia. The study was completed with a total of 32 cases. Mean age of the participants was $28.9 \pm 5.6$ and the gravida was $2.0 \pm 1.1$. Maternal hematologic, biochemical and urinary parameters of first and third trimesters were compared. In both visits, no significant difference was found in hemoglobin, hematocrit and platelet values from full blood parameters and in glucose, BUN, creatinine, ALT, AST and urinary $\mathrm{pH}$ and density values from biochemical parameters (Table 1). It was seen that both

Table 1. Comparison of maternal serum and urinary parameters according to the trimesters.

\begin{tabular}{lccc} 
& First trimester & Last trimester & P value \\
\hline s-lipocalin-2 (ng/ml) & $78.79 \pm 20.4$ & $60.48 \pm 20.69$ & 0.001 \\
u-lipocalin-2 (ng/ml) & $76.84 \pm 62.50$ & $36.34 \pm 29.79$ & 0.022 \\
Glucose (mg/dL) & $90.84 \pm 13.29$ & $92.15 \pm 13.07$ & 0.837 \\
Creatinine (mg/dL) & $0.57 \pm 0.07$ & $0.57 \pm 0.06$ & 0.705 \\
BUN (mg/dL) & $14.36 \pm 4.02$ & $14.8 \pm 3.4$ & 0.530 \\
ALT (U/L) & $11.45 \pm 4.86$ & $11.33 \pm 3.96$ & 0.893 \\
AST (U/L) & $14.62 \pm 3.15$ & $14.70 \pm 2.86$ & 0.711 \\
WBC (K/uL) & $10.93 \pm 1.68$ & $9.94 \pm 1.48$ & 0.053 \\
Hb (g/dL) & $11.3 \pm 1.08$ & $11.58 \pm 1.33$ & 0.083 \\
Hct (\%) & $33.20 \pm 2.48$ & $33.96 \pm 2.43$ & 0.172 \\
PLT (K/uL) & $236.91 \pm 61.74$ & $233.47 \pm 60.25$ & 0.431 \\
u-pH & $6.37 \pm 0.76$ & $6.14 \pm 0.56$ & 0.217 \\
Density & $1.012 \pm 0.004$ & $1013 \pm 0.005$ & 0.507 \\
\hline
\end{tabular}

ALT: alanine transaminase; AST: aspartate transaminase; BUN: blood urea nitrogen; $\mathrm{Hb}$ : hemoglobin; Hct: hematocrit; PLT: platelet; s-: serum; u-: urinary; WBC: white blood cell. 
urinary and serum lipocalin-2 levels were significantly low in the third trimester compared to the first trimester (Table 1).

\section{Discussion}

In our study, we evaluated maternal serum and urinary lipocalin-2 levels in the first and third trimesters of non-complicated pregnant women, and we found that lipocalin levels of both in urine and serum were significantly lower in the third trimester. In their study, Edelstam et al. evaluated lipocalin-2 levels on healthy pregnant women during the third trimester at 33, 36 and 39 weeks of gestation and postpartum period. They reported that lipocalin-2 levels increased depending on the week of gestation; however, these levels reached their highest values at postpartum period. ${ }^{[5]}$ They stated that increasing lipocalin-2 levels may be associated with postpartum infection.

Lipocalin-2 levels are usually the discussion topic of the studies carried out on complicated pregnancies. As being a marker to determine endothelial damage, they are used in studies on preeclampsia. ${ }^{[6]}$ The lipocalin-2 values in pregnant women complicated with preeclampsia were reported at higher levels. It was even shown that this increase induced by endothelial damage began in the second trimester and continued to increase on the third trimester. In these studies where healthy pregnant women were included as control group, it was stated that lipocalin-2 levels were stable in healthy cases. ${ }^{[6]}$ Similarly, Karampas et al. found in their longitudinal studies where healthy pregnant women were compared with pregnant women complicated with preeclampsia and growth retardation that lipocalin-2 levels were similar to normal pregnant women in all three trimesters. ${ }^{[7]}$ Ödum et al. reported that lipocalin-2 in the urine were at high levels in normal pregnant women unlike preeclampsia. ${ }^{[8]}$ However, we observed in our study that lipocalin-2 levels were not stable in normal pregnant women, and they were significantly low both in urine and serum in the third trimester compared to the first trimester.

In a study performed on 130 healthy individuals where lipocalin-2 was used to determine renal function and glomerular filtration, serum lipocalin-2 levels of non-pregnant women were compared with the values at all three trimesters of gestation. However, this was not a case-controlled study, and the values at the second trimester were high significantly. ${ }^{[9]}$
The strength of our study is to be a case-controlled study. Analysis of lipocalin-2 levels of the same patient group in urine and serum at both first and third trimesters, and significantly low results obtained in both analyses show the reliability of the study. However, small number of population, cases being preconceptional, and non-availability of second trimester and postpartum values are among the limitations of the study.

\section{Conclusion}

Lipocalin-2 is a promising marker as the early identifier of endothelial damage, and for the early diagnosis of preeclampsia as well as glucose intolerance and hyperglycemia. However, in the light of existing studies, it raises concern that lipocalin-2 levels in healthy pregnant women do not have clear standard ranges, and there are contradictory results about the progress of blood and urine levels during pregnancy. The results of our study contribute to the determination of the normal progress of lipocalin-2 in healthy pregnant women as a candidate marker to predict severe gestational complications. On the other hand, further studies with wider populations where reference ranges are determined well according to the trimesters in healthy pregnant women will help to enhance the diagnostic capabilities of lipocalin-2.

Conflicts of Interest: No conflicts declared.

\section{References}

1. Kjeldsen L, Bainton DF, Sengelov H, Borregaard N. Identification of neutrophil gelatinase-associated lipocalin as a novel matrix protein of specific granules in human neutrophils. Blood 1994;83:799-807.

2. Cowland JB, Sorensen OE, Sehested M, Borregaard N. Neutrophil gelatinase-associated lipocalin is up-regulated in human epithelial cells by IL-1 beta, but not by TNF-alpha. J Immunol 2003;171:6630-9.

3. Lou Y, Wu C, Wu M, Xie C, Ren L. The changes of neutrophil gelatinase-associated lipocalin in plasma and its expression in adipose tissue in pregnant women with gestational diabetes. Diabetes Res Clin Pract 2014;104:13642.

4. D'Anna R, Baviera G, Giordano D, Todarello G, Corrado F, Buemi M. Second trimester neutrophil gelatinase-associated lipocalin as a potential prediagnostic marker of preeclampsia. Acta Obstet Gynecol Scand 2008;87:1370-3. 
5. Edelstam G, Löwbeer C, Kral G, Gustafsson SA, Venge P. New reference values for routine blood samples and human neutrophilic lipocalin during third-trimester pregnancy. Scand J Clin Lab Invest 2001;61:583-92.

6. D'Anna R, Baviera G, Giordano D, Todarello G, Russo S, Recupero S, et al. Neutrophil gelatinase-associated lipocalin serum evaluation through normal pregnancy and in pregnancies complicated by preeclampsia. Acta Obstet Gynecol Scand 2010;89:275-8.

7. Karampas G, Eleftheriades M, Panoulis K, Rizou M, Haliassos A, Hassiakos D, et al. Maternal serum levels of neutrophil gelatinase-associated lipocalin (NGAL), matrix metalloproteinase-9 (MMP-9) and their complex MMP9/NGAL in pregnancies with preeclampsia and those with a small for gestational age neonate: a longitudinal study. Prenat Diagn 2014;34:726-33.

8. Ødum L, Andersen AS, Hviid TV. Urinary neutrophil gelatinase-associated lipocalin (NGAL) excretion increases in normal pregnancy but not in preeclampsia. Clin Chem Lab Med 2014;52:221-5.

9. Malyszko JS, Rams L, Drozdowska-Rams L, Ma6yszko J. Serum neutrophil gelatinase-associated lipocalin as a marker of kidney function in pregnancy - useful or doubtful? Arch Med Sci 2010;6:744-7. 